\title{
Identification of Rad51 alteration in patients with bilateral breast cancer
}

\begin{abstract}
The human Rad51 gene, HsRAD51, is a homolog of RecA of Escherichia coli and functions in recombination and DNA repair. BRCA1 and BRCA2 proteins form a complex with Rad51, and these genes are thought to participate in a common DNA damage response pathway associated with the activation of homologous recombination and double-strand break repair. Additionally, we have shown that the pattern of northern blot analysis of the Rad51 gene is closely similar to those of the $B R C A 1$ and $B R C A 2$ genes. It is therefore possible that alterations of the Rad51 gene may be involved in the development of hereditary breast cancer. To investigate this possibility, we screened Japanese patients with hereditary breast cancer for Rad51 mutations and found a single alteration in exon 6. This was determined to be present in the germline in two patients with bilateral breast cancer, one with synchronous bilateral breast cancer and the other with synchronous bilateral multiple breast cancer. In both patients, blood DNAs showed a G-to-A transition in the sec-
\end{abstract}

M. Kato $\cdot$ K. Yano $\cdot$ F. Matsuo $\cdot$ H. Saito $\cdot$ Y. Miki $(\bowtie)$

Department of Molecular Diagnosis, Cancer Institute, 1-37-1

Kamiikebukuro, Toshima-ku, Tokyo 170-8455, Japan

Tel. +81-3-5394-4035; Fax +81-3-5394-4035

e-mail: yosmiki@ims.u-tokyo.ac.jp

M. Kato $\cdot$ H. Nagawa

Department of Surgical Oncology, Faculty of Medicine,

The University of Tokyo, Tokyo, Japan

T. Katagiri

Cancer Genetics Laboratory, Division of Medical and Molecular

Genetics, Guy's, King's and St. Thomas' School of Medicine,

London, UK

H. Kurumizaka

Cellular Signaling Laboratory, The Institute of Physical and

Chemical Research (RIKEN), Saitama, Japan

M. Yoshimoto $\cdot$ F. Kasumi

Department of Breast Surgery, Cancer Institute Hospital, Tokyo,

Japan

F. Akiyama $\cdot$ G. Sakamoto

Department of Pathology, Cancer Institute, Tokyo, Japan

Y. Nakamura

Human Genome Center, Institute of Medical Science, University of

Tokyo, Tokyo, Japan ond nucleotide of codon 150, which results in the substitution of glutamine for arginine. As this alteration was not present in any patients with breast or colon cancer examined, we assume that this missense alteration is likely to be a disease-causing mutation.

Key words $\operatorname{Rad} 51$ - Hereditary breast cancer - BRCA1 . $B R C A 2 \cdot$ Germline alteration

\section{Introduction}

The human Rad51 gene, HsRAD51, is a homolog of RecA of Escherichia coli (Shinohara et al. 1993) and functions in DNA repair and recombination (Resnick 1987; Shinohara et al. 1992). Rad51 shares many biochemical properties with $\operatorname{Rec} A$. It binds to single- and double-stranded DNA, exhibits DNA-dependent adenosine triphosphatase (ATPase) activity, forms helical nucleoprotein filaments, and mediates homologous pairing and strand exchange between DNA molecules (Benson et al. 1994; Baumann et al. 1996; Gupta et al. 1997). The evolutionarily conserved Rad52 group of genes, of which the Rad51 gene is one, cotrols recombinational repair of DNA double-stranded breaks and other lesions in Saccharomyces cerevisiae. Rad51 protein performs crucial functions in this process (Game 1993). Mutations in Rad51 cause reduced meiotic and mitotic recombination, hypersensitivity to ionizing radiation and methylmethanesulfonate, and a deficiency in the repair of DSBs.

The two major hereditary breast cancer susceptibility genes, $B R C A 1$ and $B R C A 2$, are associated with familial breast cancer, ovarian cancer, or both. Germline mutations in the BRCA1 gene increase the risk of development of early-onset breast cancer and ovarian cancer (Miki et al. 1994). Alterations in the $B R C A 2$ gene result in an increased risk of development of breast cancer in both women and men (Wooster et al. 1995), and a moderately increased risk of a variety of other cancers including carcinomas of the ovary, pancreas, prostate, and colon (Gudmundsson et al. 
1995). As the inactivation of both alleles of either $B R C A 1$ or $B R C A 2$ is a key feature in neoplastic development in hereditary cancers, these genes are believed to act as tumor suppressor genes required for cell growth. Several studies have demonstrated that BRCA1 and BRCA2 proteins form a complex with Rad51 (Scully et al. 1997; Sharan et al. 1997; Katagiri et al. 1998), and these genes are thought to participate in a common DNA damage response pathway associated with the activation of homologous recombination and double-strand break repair.

In the present study, we show that the pattern of northern blot analysis of the Rad51 gene is closely similar to those of the BRCA1 and BRCA2 genes. Dysfunction of this pathway may be a general phenomenon in the majority of cases of hereditary breast cancer, ovarian cancer, or both. Mutations in one or the other of these genes are involved in approximately $60 \%$ of familial breast cancers in Japan (Katagiri et al. 1998; Noguchi et al. 1999). Taken together, these results indicate the existence of a third major gene responsible for hereditary breast cancers. It is therefore possible that alterations of the Rad51 gene may be involved in the development of hereditary breast cancers. To investigate this possibility, we screened Japanese patients with hereditary breast cancers for Rad51 mutations, using polymerase chain reaction-single-strand conformation polymorphism (PCR-SSCP) analysis.

\section{Subjects and methods}

\section{Subjects}

Twenty unrelated families showing a pattern of inheritance of breast cancer were evaluated. For each family, a pedigree was prepared on the basis of a family member known to be affected. The criteria for selection of "breast-cancer families" for this study were as follows: (i) at least three first-degree family members with breast cancer, or (ii) two or more first-degree family members with breast cancer, either early-onset, bilateral, or accompanied by a history of primary cancer(s) of other organs. In addition, we selected 25 patients with breast cancer, either early-onset, bilateral, or accompanied by a history of primary cancer(s) of other organs, whose onset seemed to be associated with dysfunc- tion of genetic factor(s). We obtained informed consent for the genetic study from these patients. Blood samples were obtained from affected family members and genomic DNAs were extracted from fresh blood under standard protocols (Sambrook et al. 1989).

\section{Northern blot analysis}

Human tissue blots, containing in each lane $2 \mu \mathrm{g}$ poly (A) + RNA from one of 16 different normal tissues (Clontech, Palo Alto, CA, USA) were hybridized with full-length cDNA of Rad51. Blots were prehybridized for $4 \mathrm{~h}$ and hybridized for $16 \mathrm{~h}$ at $42^{\circ} \mathrm{C}$ in a solution containing $50 \%$ formamide, $5 \times$ Denhardt, $5 \times$ saline sodium phosphate ethylenediaminetetraacetic acid (SSPE), 2\% sodium dodecylsulfate (SDS), and $100 \mu \mathrm{g} / \mathrm{ml}$ of denatured salmon sperm DNA. The blots were washed in $2 \times$ saline sodium citrate (SSC) for $10 \mathrm{~min}$ at room temperature and twice in $0.1 \times \mathrm{SSC}$ and $0.1 \% \mathrm{SDS}$, for $20 \mathrm{~min}$ each time, at $55^{\circ} \mathrm{C}$ before being autoradiographed at $-80^{\circ} \mathrm{C}$ for $16 \mathrm{~h}$.

\section{SSCP analysis}

The entire coding sequences of Rad51 and associated exonintron boundary sequences were examined by PCR-SSCP analysis. The primers used for PCR-SSCP analysis are described in Table 1. Each genomic DNA (50ng) was amplified in a reaction mixture containing $10 \mu \mathrm{l}$ of $1 \times$ PCR buffer $(25 \mathrm{mM}$ N-tris [Hydroxymethyl] methyl-3aminopropanesulfonic acid [TAPS], $50 \mathrm{mM} \mathrm{KCl}, 2 \mathrm{mM}$ $\mathrm{MgCl} 2$, and $1 \mathrm{mM}$ beta-mercaptoethanol), $20 \mu \mathrm{M}$ dNTPs, $5 \mathrm{pmol}$ primers, $2 \mu \mathrm{Ci}$ of $\left[\alpha{ }^{32} \mathrm{P}\right] \mathrm{dCTP}(3000 \mathrm{Ci} / \mathrm{mmol}$; $10 \mathrm{mCi} / \mathrm{ml}$ ), and 0.5 units of Taq polymerase (Takara, Kyoto, Japan). PCR conditions consisted of one cycle at $94^{\circ} \mathrm{C}$ for $2 \mathrm{~min}$, then 30 cycles at $94^{\circ} \mathrm{C}$ for $30 \mathrm{~s}, 55^{\circ} \mathrm{C}$ for $30 \mathrm{~s}$, and $72^{\circ} \mathrm{C}$ for $30 \mathrm{~s}$, with final elongation at $72^{\circ} \mathrm{C}$ for $5 \mathrm{~min}$. Each reaction mixture was diluted with $50 \mu$ l of $95 \%$ formamide dye and $20 \mathrm{mM}$ ethylenediaminetetraacetic acid (EDTA), incubated at $95^{\circ} \mathrm{C}$ for $5 \mathrm{~min}$, and electrophoresed in a $6 \%$ polyacrylamide gel containing $5 \%$ glycerol and $0.5 \times$ TBE $(90 \mathrm{mM}$ Tris-borate $/ 2 \mathrm{mM}$ EDTA $)$ maintained at $4^{\circ} \mathrm{C}$ and $16^{\circ} \mathrm{C}$, under two different conditions: $400 \mathrm{~V}$ at $4^{\circ} \mathrm{C}$ and $1200 \mathrm{~V}$ at $16^{\circ} \mathrm{C}$. The gel was dried and autoradiographed with an intensifying screen. When vari-

Table 1. Sequence of Rad51 primers used for PCR-SSCP analysis

\begin{tabular}{|c|c|c|c|c|}
\hline Exon & Sense primer & Antisense primer & $\begin{array}{l}\text { Product } \\
\text { size (bp) }\end{array}$ & $\begin{array}{l}\text { Annealing } \\
\text { temperature }\left({ }^{\circ} \mathrm{C}\right)\end{array}$ \\
\hline 2 & TCTAGTGTTTATACTGATAAGC & TTCCACTAGGTAGAAGAATCT & 183 & 55 \\
\hline 3 & TATCCATGGTTTTCTTCATTTG & TCCСТAGGTTAAGTAAGCAG & 190 & 55 \\
\hline 4 & CAAGATCACTGTGGTAAGGAA & ACAACACAGGATAAAGGATTAC & 202 & 55 \\
\hline 5 & ATGCTAAGAGTTATTTCTTATC & GATTAGCTATAGCCCCAACA & 150 & 55 \\
\hline 6 & AAGATGTCATGAGGAGCTTGG & GCCATAGTCTCTCTTATCTAAACCAG & 205 & 55 \\
\hline 7 & TTCTGTGTGCAGCCTAAAAAT & ACTCTTAAGAACATATTTGGTG & 195 & 55 \\
\hline 8 & AATAGGCTTCAGAGAATCCTT & CTCTGTCCСТАТCCCACAA & 186 & 55 \\
\hline 9 & ATGGCCACAAAATTGACATTTA & CATTCCGAAAAGAAGAACTG & 197 & 55 \\
\hline 10 & TTATAATAAATTGGTGCTTTGGT & ТTTTAACAGAGGAAAAACCСАA & 190 & 55 \\
\hline
\end{tabular}

PCR-SSCP, Polymerase chain reaction-single-strand conformation polymorphism 
ant bands were detected on SSCP analysis, DNAs were amplified by PCR and electrophoresed on $2 \%$ agarose gel, extracted from the gel, and subcloned into pT7-BlueTVector (Novagen, Madison, WI, USA). At least 50 clones were pooled together and DNAs were extracted as sequence templates. Their nucleotide sequences were determined by dideoxy-chain termination with T7 DNA polymerase, using gene-specific primers to identify the nature of the mutation. All results were confirmed by two independent experiments.

\section{Results}

\section{Northern blotting}

As shown in Fig. 1A, hybridization of RNA blots to labeled fragment of Rad51 cDNA revealed a single transcript of approximately $2 \mathrm{~kb}$. This transcript was most abundant in testis and thymus, but was also present in small intestine, placenta, colon, pancreas, and ovary. Expression of the Rad51 gene in breast tissues was confirmed by reverse transcription (RT)-PCR experiments (Fig. 1B). The tissue ex-
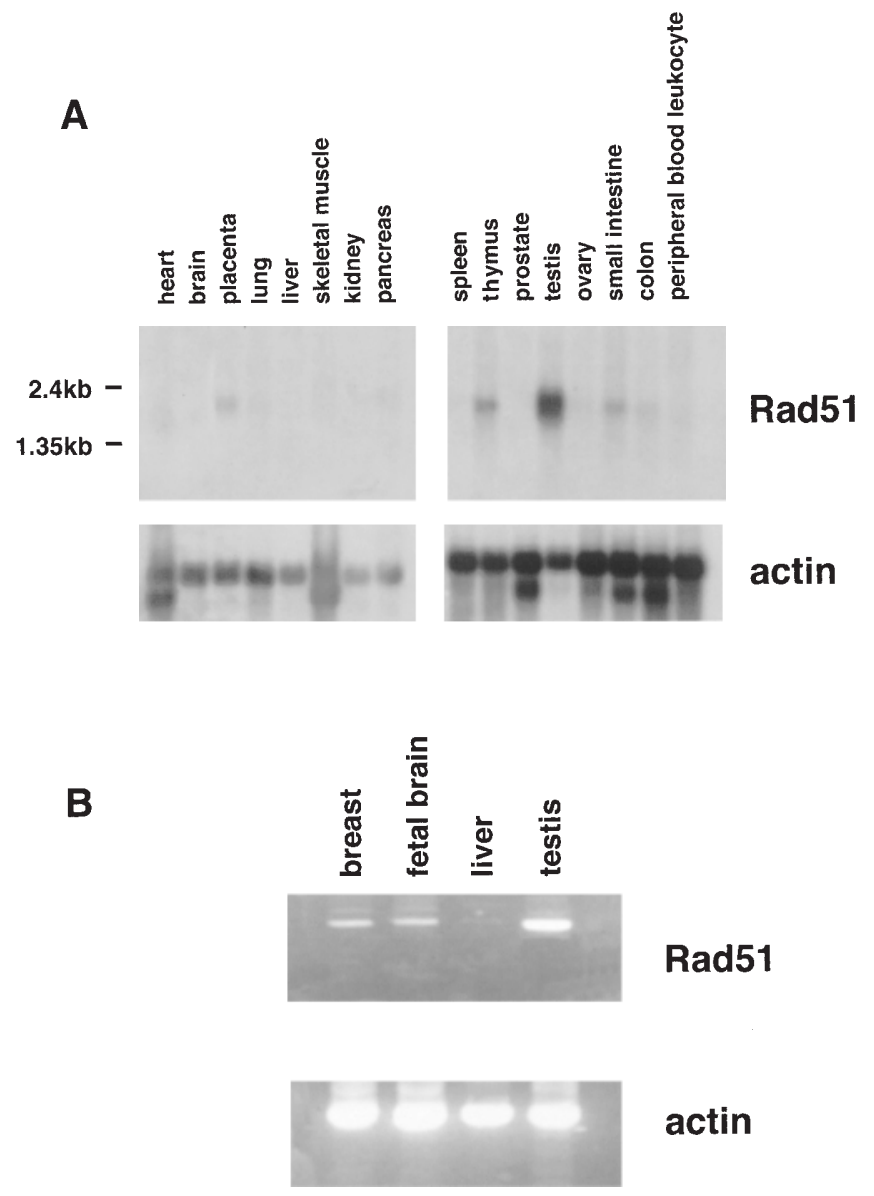

Fig. 1. A Northern blot analysis of Rad51 in various human adult tissues. RNA size markers are indicated at left, and the tissues from which RNAs were obtained are shown above the corresponding lanes. B Reverse transcription-polymerase chain reaction (RT-PCR) analysis of Rad51 mRNA expression in the breast pression pattern of the Rad51 gene was found to be closely similar to those of the $B R C A 1$ and $B R C A 2$ genes (Miki et al. 1994; Tavtigian et al. 1996).

\section{Mutation analysis of Rad51}

Genomic DNAs were obtained from 20 patients in breast cancer families, and from 25 patients with breast cancers, either early-onset, bilateral, or accompanied by a history of primary cancer(s) of other organs, whose onset seemed to be associated with dysfunction of genetic factor(s). To evaluate whether the Rad51 gene was altered in patients with breast cancer, we screened the entire coding sequence and intronic sequences flanking each of its exons for mutations, using PCR-SSCP. Table 1 summarizes the primers used for the amplification of each single exon. The DNA sequences of PCR products obtained from DNAs corresponding to SSCP variants were determined.

Results revealed a single alteration in exon 6 , which was determined to be present in the germline in two patients with bilateral breast cancers. Representative autoradiograms of PCR-SSCP and sequence analysis of the Rad51 gene in one of the two patients are shown in Fig. 2. One patient was a 52-year-old woman with synchronous bilateral breast cancer (patient I, histopathology; noninvasive ductal carcinoma) and the other patient was a 44-year-old woman with synchronous bilateral multiple breast cancer (patient II, histopathology; invasive ductal carcinoma). Patient I had no family history of breast cancer, and the family history of patient II was unknown. In both patients, blood DNAs showed a G-to-A transition of the second nucleotide of codon 150 , which results in the substitution of glutamine for arginine. The normal allele was present in these samples, indicating that the patients were heterozygous for the alteration. To examine two-hit inactivation, we analyzed the status of Rad51 alleles in the breast tumors of the two patients. Each of the genomic DNAs from tumor tissues was amplified by PCR and subcloned into pT7-BlueT-Vector. Ten clones from ten colonies were sequenced for codon 150 alteration of Rad51. In one case (patient II), we detected far more mutated alleles than normal alleles. Results were confirmed by three independent experiments. In consideration of normal tissue contamination, we concluded that patient II had loss of the normal allele. Furthermore, we screened for this base substitution in 200 patients with sporadic breast cancers and 100 patients with colon cancers. As this alteration was not detected in any patients examined, we assume that this missense alteration is likely to be a disease-causing mutation. Apart from this alteration, no other sequence variants were observed.

\section{Discussion}

Mutation of the $B R C A 1$ gene is thought to be the causative factor in approximately $30 \%$ of hereditary breast cancer families. Moreover, the proportion of early-onset breast 
Fig. 2A-C. Representative autoradiograms of PCR- single-strand conformation polymorphism (SSCP) and sequence analysis of exon 6 in Rad51. A PCR-SSCP analysis of exon 6 in rad51 from patient I. (I). Arrow indicates the aberrant band. B Sequence analysis of exon 6 from normal control. C Sequence analysis of exon 6 from patient I
Exon 6

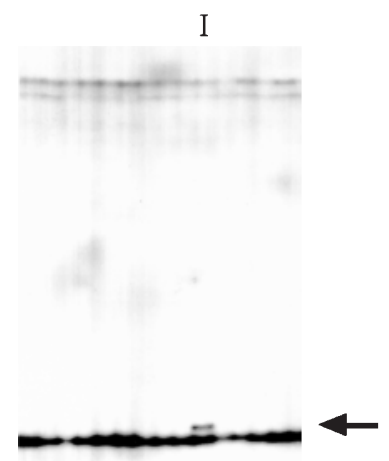

cancer accounted for by the BRCA2 and $B R C A 1$ genes appears to be roughly equal (Couch et al. 1997; Noguchi et al. 1999). The remaining susceptibility to early-onset breast cancer is likely attributable to unmapped genes for familial cancer and rare germline mutations in genes such as TP53 and PTEN (Srivastava et al. 1990; Malkin et al. 1990; Liaw et al. 1997). The isolation of unmapped genes responsible for the remaining susceptibility is important for the genetic testing of hereditary breast cancer, as well as for the understanding of breast carcinogenesis.

There is no direct evidence that cancer occurs through defects in repair processes involving homologous recombination. NBS1, a member of the hMRE11/Hrad50 recombination protein complex, was shown to be mutated in Nijmegen breakage syndrome, which is characterized by increased cancer incidence and ionizing radiation sensitivity (Varon et al. 1998; Carney et al. 1998; Matsuura et al. 1998), suggesting that a defect in recombination leads to tumor development. Rad51 acts as a complex with breast cancer susceptibility gene products BRCA1 and BRCA2, and the tissue expression patterns of the three genes are very similar. These gene products participate in a common DNA damage response pathway. Components of this pathway would be required for the stability of genetic information, and their loss would be expected to result in an elevated mutation rate, and lead to the accumulation of DNA damage and, hence, to increased cancer risk.

Based on these considerations, we investigated here the possibility that Rad51 might be a breast cancer-predisposing gene, and detected one alteration of Rad51 in two patients with bilateral breast cancers. The amino acid substitution of a neutral residue (Gln) for a basic residue (Arg) detected here is reported as a missense mutation of the TP53 gene, and no sequence variants in Rad51 have been found previously (Schmutte et al. 1999; Bell et al. 1999). In addition, both patients with this alteration were diagnosed as having synchronous bilateral breast cancers, and this alteration was not present in more than 300 patients with breast or colon cancers. We therefore assume that this alteration is likely to represent a disease-associated mutation. Segregation or functional analysis should be performed to exclude the possibility that the nucleotide change is a rare polymorphism. Common genetic variations, including single base substitution, have recently assumed considerable importance, because even a modest increase in cancer risk associated with a polymorphism may be significant. The $11307 \mathrm{~K}$ mutation in the $A P C$ gene is common in the Ashkenazi Jewish population and is associated with a moderately increased risk of colon cancer (Laken et al. 1997). Even if the single base substitution described here is a rare polymorphism, it is possible that this alteration may be related to bilateral breast cancer. Further work will be required to determine whether this alteration displays any deficiency in DNA repair.

We have described the possibility that a small proportion of bilateral breast cancers is due to germline alterations of Rad51. However, the third major breast cancer susceptibility gene remains unknown; intense efforts will be required to isolate the gene(s) responsible.

Acknowledgments The authors thank K. Morotomi for technical assistance.

This work was supported by a Grant-in-Aid for General Scientific Research from the Ministry of Education Science, Sports, and Culture of Japan.

\section{References}

Baumann P, Benson FE, West SC (1996) Human Rad51 protein promotes ATP-dependent homologous pairing and strand transfer reactions in vitro. Cell 87:757-766

Benson FE, Stasiak A, West SC (1994) Purification and characterization of the human Rad51 protein, an analogue of E. coli RecA. EMBO J 13:5764-5771

Carney JP, Maser RS, Olivares H, Davis EM, Le Beau M, Yates JR 3rd, Hays L, Morgan WF, Petrini JH (1998) The hMre11/hRad50 protein complex and Nijmegen breakage syndrome: linkage of double-strand break repair to the cellular DNA damage response. Cell 93:477-486 
Schmutte C, Tombline G, Rhiem K, Sadoff MM, Schmutzler R, von Deimling A, Fishel R (1999) Characterization of the human Rad51 genomic locus and examination of tumors with 15q14-15 loss of heterozygosity (LOH). Cancer Res 59:4564-4569

Couch FJ, DeShano ML, Blackwood MA, Calzone K, Stopfer J, Campeau L, Ganguly A, Rebbeck T, Weber BL (1997) BRCA1 mutations in women attending clinics that evaluate the risk of breast cancer. N Engl J Med 336:1409-1415

Bell DW, Wahrer DC, Kang DH, MacMahon MS, FitzGerald MG, Ishioka C, Isselbacher KJ, Krainer M, Haber DA (1999) Common nonsense mutations in RAD52. Cancer Res 59:3883-3888

Game JC (1993) DNA double-strand breaks and the RAD50-RAD57 genes in Saccharomyces. Semin Cancer Biol 4:73-83

Gudmundsson J, Johannesdottir G, Bergthorsson JT, Arason A, Ingvarsson S, Egilsson V, Barkardottir RB (1995) Different tumor types from BRCA2 carriers show wild-type chromosome deletions on 13q12-q13. Cancer Res 55:4830-4832

Gupta RC, Bazemore LR, Golub EI, Radding CM (1997) Activities of human recombination protein Rad51. Proc Natl Acad Sci USA 94:463-468

Katagiri T, Kasumi F, Yoshimoto M, Nomizu T, Asaishi K, Abe R, Tsuchiya A, Sugano M, Takai S, Yoneda M, Fukutomi T, Nanba K, Makita M, Okazaki H, Hirata K, Okazaki M, Furutsuma Y, Morishita Y, Iino Y, Karino T, Ayabe H, Hara S, Kajiwara T, Houga S, Shimizu T, Toda M, Yamazaki Y, Uchida T, Kunimoto K, Sonoo H, Kurebayashi J, Shimotsuma K, Nakamura Y, Miki Y (1998) High proportion of missense mutations of the BRCA1 and BRCA2 genes in Japanese breast cancer families. J Hum Genet 43:42-48

Katagiri T, Saito H, Shinohara A, Ogawa H, Kamada N, Nakamura Y, Miki Y (1998) Multiple possible sites of BRCA2 interacting with DNA repair protein RAD51. Genes Chromosomes Cancer 21:217222

Laken SJ, Petersen GM, Gruber SB, Oddoux C, Ostrer H, Giardiello FM, Hamilton SR, Hampel H, Markowitz A, Klimstra D, Jhanwar S, Winawer S, Offit K, Luce MC, Kinzler KW, Vogelstein B (1997) Familial colorectal cancer in Ashkenazim due to a hypermutable tract in APC. Nat Genet 17:79-83

Liaw D, Marsh DJ, Li J, Dahia PL, Wang SI, Zheng Z, Bose S, Call KM, Tsou HC, Peacocke M, Eng C, Parsons R (1997) Germline mutations of the PTEN gene in Cowden disease, an inherited breast and thyroid cancer syndrome. Nat Genet 16:64-67

Malkin D, Li FP, Strong LC, Fraumeni JF Jr, Nelson CE, Kim DH, Kassel J, Gryka MA, Bischoff FZ, Tainsky MA, Friend SH (1990) Germ line p53 mutations in a familial syndrome of breast cancer, sarcomas, and other neoplasms. Science 30;250:1233-1238

Matsuura S, Tauchi H, Nakamura A, Kondo N, Sakamoto S, Endo S, Smeets D, Solder B, Belohradsky BH, Der Kaloustian VM, Oshimura M, Isomura M, Nakamura Y, Komatsu K (1998) Positional cloning of the gene for Nijmegen breakage syndrome. Nat Genet 19:179-181

Miki Y, Swensen J, Shattuck-Eidens D, Futreal PA, Harshman K, Tavtigian S, Liu Q, Cochran C, Bennett LM, Ding W, Bell R, Rosenthal J, Hussey C, Tran T, McClure M, Frye C, Hattier T,
Phelps R, Haugen-Strano A, Katcher H, Yakumo K, Gholami Z, Shaffer D, Stone S, Bayer S, Wray C, Bogden R, Dayananth P, Ward J, Tonin P, Narod S, Bristow PK, Norris FH, Helvering L, Morrison P, Rosteck P, Lai M, Barrett JC, Lewis C, Neuhausen S, CannonAlbright L, Goldgar D, Wiseman R, Kamb A, Skolnick MH (1994) A strong candidate for the breast and ovarian cancer susceptibility gene BRCA1. Science 266:66-71

Noguchi S, Kasugai T, Miki Y, Fukutomi T, Emi M, Nomizu T (1999) Clinicopathologic analysis of BRCA1- or BRCA2-associated hereditary breast carcinoma in Japanese women. Cancer 85:2200-2205

Resnick MA (1987) Investigating the genetic control of biochemical events in meiotic recombination. In Meiosis: P. B. Moens (ed) Academic, New York: 157-210

Sambrook J, Fritsch EF, Maniatis T (1989) Molecular cloning:a laboratory manual, 2nd edn. Cold Spring Harbor Laboratory Press, Cold Spring Harbor, NY

Scully R, Chen J, Plug A, Xiao Y, Weaver D, Feunteun J, Ashley T, Livingston DM (1997) Association of BRCA1 with RAD51 in mitotic and meiotic cells. Cell 88:265-275

Sharan SK, Morimatsu M, Albrecht U, Lim D-S, Regal E, Dinh C, Sands A, Eichele G, Hasty P, Bradley A (1997) Embryonic lethality and radiation hypersensitivity mediated by Rad51 in mice lacking Brca2. Nature 386:804-810

Shinohara A, Ogawa H, Ogawa T (1992) RAD51 protein involved in repair and recombination in $S$. cerevisiae is a recA-like protein. Cell 69:457-470

Shinohara A, Ogawa H, Matsuda Y, Ushio N, Ikeo K, Ogawa T (1993) Cloning of human, mouse and fission yeast recombination genes homologous to RAD51 and recA. Nature Genet 4:239-243

Srivastava S, Zou ZQ, Pirollo K, Blattner W, Chang EH (1990) Germline transmission of a mutated $p 53$ gene in a cancer-prone family with Li-Fraumeni syndrome. Nature 348:747-749

Tavtigian SV, Simard J, Rommens J, Couch F, Shattuck-Eidens D, Neuhausen S, Merajver S, Thorlacius S, Offit K, Stoppa-Lyonnet D, Belanger C, Bell R, Berry S, Bogden R, Chen Q, Davis T, Dumont M, Frye C, Hattier T, Jammulapati S, Janecki T, Jiang P, Kehrer R, Leblanc JF, Mitchell JT, McArthur-Morrison J, Nguyen K, Peng Y, Samson C, Schroeder M, Snyder SC, Steele L, Stringfellow M, Stroup C, Swedlund B, Swensen J, Teng D, Thomas A, Tran T, Tranchant M, Weaver-Feldhaus J, Wong AKC, Shizuya H, Eyfjord JE, Cannon-Albright L, Labrie F, Skolnick MH, Weber B, Kamp A, Goldgar DE (1996) The complete BRCA2 gene and mutations in chromosome 13q-linked kindreds. Nat Genet 12:333-337

Varon R, Vissinga C, Platzer M, Cerosaletti KM, Chrzanowska KH, Saar K, Beckmann G, Seemanova E, Cooper PR, Nowak NJ, Stumm M, Weemaes CM, Gatti RA, Wilson RK, Digweed M, Rosenthal A, Sperling K, Concannon P, Reis A (1998) Nibrin, a novel DNA double-strand break repair protein, is mutated in Nijmegen breakage syndrome. Cell 93:467-476

Wooster R, Bignell G, Lancaster J, Swift S, Seal S, Mangion J, Collins N, Gregory S, Gumbs C, Micklem G (1995) Identification of the breast cancer susceptibility gene BRCA2. Nature 378:789792 